\title{
EDITORIAL
}

\section{Indonesian pharmacy education, workforce challenges, and responses to the global pandemic of COVID-19}

\author{
Desak Ketut Ernawati ${ }^{1,4}$, Franciscus Cahyo Kristianto ${ }^{2,4}$, Yosef Wijoyo 3,4 \\ ${ }^{1}$ Faculty of Medicine, Udayana University, Bali \\ ${ }^{2}$ Faculty of Pharmacy, University of Surabaya, Surabaya \\ ${ }^{3}$ Faculty of Pharmacy, Sanata Dharma University, Yogyakarta \\ ${ }^{4}$ Ikatan Apoteker Indonesia, Jakarta
}

\author{
Correspondence \\ Desak Ketut Ernawati \\ Faculty of Medicine \\ Udayana University \\ Jalan PB Sudirman \\ Denpasar \\ Bali \\ Indonesia \\ ketuternawati@unud.ac.id
}

\begin{abstract}
Indonesia is an archipelago country that has a wide range of economic and social differences across the country. The COVID-19 pandemic has led to unprecedented challenges to multidimensional aspects of human life globally. This pandemic has also disrupted the education sector. Pharmacy education is no exception to the pandemic challenges. This manuscript overviews challenges and responses to the COVID-19 pandemic into the pharmacy education (initial education and pre-registration training) and pharmacy professions in Indonesia.
\end{abstract}

Since the first confirmed case of COVID-19 in Indonesia mid-March 2020, the Ministry of Education and Culture has started the closure of schools, colleges, and universities to reduce the growing number of COVID-19 cases across the country. In June 2020, the Ministry published a guideline for conducting the first semester of 2020 for a higher education degree (Dikti, 2020). The guideline covers planning, delivery, and assessment of online learning, based on facilities available in higher education degrees. Universities which have sufficient human resources and supportive infrastructure may be able to manage to shift from face to face learning to an online learning platform. Other universities may have some difficulties with the dramatic changes in the class delivery model, planning, and assessment methods as a result of this pandemic.
The Indonesian Government policy to shift all teaching and learning activities online has interrupted pharmacy education programmes across the country. In accordance, the Indonesian Association of Pharmacy Higher Education - APTFI (Asosiasi Perguruan Tinggi Farmasi Indonesia) also instructed universities to recall all pharmacy internship students. At the beginning of the pandemic, both lecturers and students were unprepared, due to the short notice of dramatic changes. The most significant issue experienced by academics and students was the lack of Internet access and limited data for the connection. Thus, some education institutions conducted training on how to deliver online learning for academics as well as provided Internet quota for disadvantaged students. The Internet quota supports were also given by national and private communication providers in Indonesia. In addition, the Indonesian 
Ministry of Education is currently pursuing to provide quota for Indonesian students.

A few months after the start of the pandemic, online teaching and learning delivery became more organised because many education institutions shared their webinars on how to deliver online learning and uploaded amateur videos on using the learning management systems (LMS, e.g. Moodle). Online teaching activities were delivered through virtual meeting technologies such as Zoom, Google Meet, and Cisco. Pharmacy academics also started to record their lectures and upload them in their LMS. Some pharmacy education institutions also held training on synchronous and asynchronous learning and flipped classrooms for academics. Further, the APTFI facilitated the use of online learning in pharmacy education through online learning contests which can be employed by lecturers across the country. The association also highlighted that although pharmacy internship programmes may proceed, placement at the hospital, in particular, must put the students' and patients' safety as the priority.

Another challenge in pharmacy education was in achieving technical skills competence. Before the pandemic, competence was delivered and assessed during placement at practice sites. To face challenges in this instance, the academics provided videos or posters of practical experience as case study scenarios. The pharmacy students discussed the cases and learned the solutions to the problems of the cases. Since August 2020, the education institutions may resume offline technical and laboratory activities with a strict health protocol. The education institutions must meet the requirement that the institutions are in green or yellow zones before conducting offline teaching and learning activities. The zones are determined by the Indonesian COVID-19 task force and the institutions must get their permission to have offline teaching and learning activities (Gugus Tugas Percepatan Penanganan COVID-19, 2020). Further, the registration process of pharmacy students who completed their degrees has been affected. Their registration was delayed and thus, online 'oath-taking' was held. Meanwhile, institutions in the green zone may have the 'oath-taking' offline with strict health protocols.

Similar to the pharmacy education level, the Indonesian Pharmacist Association - IAI (Ikatan Apoteker Indonesia), as the professional body for pharmacist organisation in Indonesia, is also facing the same challenges. Before the pandemic, continuing professional development events in the country were conducted as face to face seminars. During the pandemic, all professional pharmacist development programmes are conducted online.
Adjustments are made to the planning, delivery, and evaluation of the success of the programme regarding the pharmacists' competencies development.

Currently, there are more than 70,000 registered pharmacists in Indonesia. Before the pandemic, regular seminars were delivered offline across the 34 provinces in Indonesia. However, after the start of the pandemic, all offline activities were postponed, including an annual national meeting which was planned for April 2020. As a result, demands on online learning increased, yet IAI faced some difficulties. Between early April and mid-August, IAI delivered more than 50 free, centralised online webinars via virtual meeting platforms (i.e. Zoom) which could accommodate thousands of pharmacists in Indonesia. The webinars are now conducted twice a month. Topics on the webinars range from hot issues such as understanding of COVID-19 management and vaccine developments to the dissemination of an online platform for members. The platform was labelled as a pharmacist information system - SIAP (Sistem Informasi Apoteker). The introduction of the online platform was considered as timely, since understanding the platform allows pharmacists in Indonesia to update their memberships and to complete their portfolio for continuing professional development requirements. This shows that IAI has implemented one of the goals on workforce intelligence of the Workforce Development Goals (WDGs).

Other topics also came from members' requests and invited speakers. Topics requested from members included regular updates on non-communicable diseases such as hypertension, cardiovascular diseases, and infectious diseases. The invited speakers in the webinars were the National Food and Drug Agency - BPOM (Badan Pengawasan Obat dan Makanan), faculty members, and other health professions. Having webinars in collaboration with other health professionals was considered as a facilitator on domain of working with others in the workforce development goals. In the webinar, pharmacists learned from pulmonologists, paediatricians, cardiologists, internists, and dermatologists about updates on topics related to the speaker's expertise. Another topic of the webinar was on electronic information and transaction law which aimed to enhance pharmacists' knowledge on using electronic information and transaction wisely. Although online webinars may replace offline seminars during the pandemic, some pharmacists were unable to attend all webinars due to a limited number of participants in each webinar. Thus, some recorded webinars were made available in SIAP.

Another difficulty IAI may face during this pandemic is their preparedness to provide a more structured topic for 
professional development. The various topics presented in the previous webinars reflected unstructured learning within pharmacy professions. This requires future redesign of pharmacy learning to meet the needs of a more competent health workforce with structured, continuing professional development. The pharmacists need to reflect their individual assessment on how they enhance their professionals' competence. The workforce transformation programme, which is currently being developed by IAI in collaboration with FIP (International Pharmaceutical Federation), should fill the gap on the needs of preparing a more competent health workforce through an adopted advance framework - KLP3A (Kerangka Lanjutan Pengembangan Praktek Profesi Apoteker). It is expected that the framework will facilitate future pharmacists to progress towards a competent health workforce in the universal health coverage. The adoption of this framework is one of IAl's commitments to accommodate WDGs on advanced practice and specialisation.

Despite the fact that pharmacy education faces challenges during the COVID-19 pandemic, the education institutions are required to maintain the needs of high order thinking skills as the output of their programme, while ensuring the online platform employed is quota friendly to the students. From the pharmacy practice perspective, the needs of community pharmacists to practice during this pandemic is emerging. The government's primary and secondary health services are providing their service during the pandemic (PMK Republik Indonesia Nomor 9 Tahun, 2020). As a result, pharmacies across the country are required to remain open as the primary health facility for their community. Challenges were also experienced at the beginning of the pandemic, such as limited stocks and the increase in price of masks and hand sanitisers across the country. The community pharmacies also need to protect their customers and staff during this pandemic. Thus, having face shields for the staff, providing hand sanitisers to customers, and providing layers at the front counters are mandatory for minimising the risk of viral exposure at community pharmacies. This pandemic has improved the role of pharmacists as an essential component of healthcare professionals in the community. Thus, community pharmacists need to increase their competence to meet the needs of the population.

To conclude, of the current WDGs, IAI has addressed advanced and specialist development, working with others, and workforce intelligence. Other goals require future work, in collaboration with stakeholders involved, to ensure Indonesian pharmacists will be ready to take part during this pandemic and in the universal health coverage.

\section{References}

Dikti, D. (2020). Buku Panduan Penyelenggaraan Pembelajaran Semester Gasal 2020/2021 di Perguruan Tinggi. 29.

Gugus Tugas Percepatan Penanganan COVID-19. (2020). Peta Zonasi Resiko Available at: https://covid19.go.id/peta -risiko

PMK Republik Indonesia Nomor 9 Tahun 2020. (2020). Pedoman Pembatasan Sosial Berskala Besar Dalam Rangka Percepatan Penanganan Corona Virus Disease 2019 (Covid-19). Kementerian Kesehatan RI, 28. Available at: http://hukor.kemkes.go.id/ uploads/produk_hukum/PMK_No_9_Th_2020_ttg_Pedoman Pembatasan Sosial Berskala Besar Dalam Penanganan COVI D-19.pdf 